\title{
Correction: My approach to endoscopic ultrasound-guided fine-needle aspiration biopsy specimens of the pancreas
}

Wong NACS. My approach to endoscopic ultrasound-guided fine-needle aspiration biopsy specimens of the pancreas. J Clin Pathol. 2020;73:297-309. doi: 10.1136/jclinpath-2019-206331.

This article was previously published with an error.

In the first paragraph of the 'Cystic lesions' section, the expansion of the abbreviation ABDPAS should read as Alcian blue diastase-treated periodic acidic Schiff.

(C) Author(s) (or their employer(s)) 2020. No commercial re-use. See rights and permissions. Published by BMJ.

J Clin Pathol 2020;73:e1. doi:10.1136/jclinpath-2019-206331corr1

(D) Check for updates 